\title{
Postmenopozal kadınlarda diyet inflamatuar indeksi ve kırık insidansı ilişkisi
}

\section{Relationship between dietary inflammatory index and fracture incidence in postmenopausal women}

\author{
Betül YILDIRIM ÇAVAK ${ }^{\mathrm{a} 1, *}$, Serap ANDAÇ ÖZTÜRK ${ }^{\mathrm{b} 2}$ \\ a İstanbul Aydın Üniversitesi Sağlık Bilimleri Enstitüsü, Beslenme ve Diyetetik ABD, İstanbul \\ $\mathrm{b}$ İstanbul Aydın Üniversitesi Săglık Bilimleri Fakültesi, Beslenme ve Diyetetik Bölümü, İstanbul
}

İstanbul Sabahattin Zaim Üniversitesi Fen Bilimleri Enstitüsü Dergisi (2020) 2 (3): 13-18

https://doi.org/10.47769/izufbed.750439

ORCID Numaraları:

${ }^{1}$ 0000-0002-1540-4505

${ }^{2}$ 0000-0002-6253-4118

\begin{tabular}{l}
\hline YAYIN BİLGİSI \\
\hline Yayın geçmişi: \\
Gönderilen tarih: 11 Haziran 2020 \\
Kabul tarihi: 17 Ekim 2020
\end{tabular}

\section{Anahtar kelimeler:}

Diyet inflamatuar indeksi

İnflamasyon

Kemik sağ $\operatorname{liğ}_{1}$

Postmenopozal dönem

\section{Key words:}

Diet inflammatory index

Inflammation

Bone health

Postmenopausal period

\section{ÖZET}

İnflamasyon, inflamatuar uyaran veya doku hasarına karşı vücudun immün yanıtıdır. Akut inflamasyon yaralanma ve enfeksiyoz ajanlara karşı gelişirken, kronik inflamasyon insülin direnci, diyabet, ateroskleroz, obezite ve metabolik sendrom ile ilişkilidir. Diyet içeriği serumda CRP, IL-6 ve TNF- $\alpha$ gibi inflamasyon parametreleri üzerine etkisiyle kronik inflamasyona sebep olabilmektedir. Diyette gereksinimden fazla enerji alımı inflamatuar süreçleri tetikler. Bunun yanı sıra diyette yer alan makro- ve mikro besin ögeleri inflamatuar süreçler üzerinde etkilidir. Makro besin ögeleri olan karbonhidrat, protein ve yağların kaynağı, türü ve miktarı inflamasyon parametrelerini etkiler. Diyetin basit karbonhidrattan zengin olması, yüksek glisemik indeks, yüksek yağ (özellikle trans yağ asitlerinin fazlalığı) ve kolesterol içermesi CRP, TNF- $\alpha$, IL-6, IL$1 \beta$ gibi pro-inflamatuar moleküllerin salınımını arttırmaktadır. Buna karşın diyetin posa, MUFA ve Omega-3 içeriğinin yüksek olması ise inflamatuar yanıt oluşumuna karşı koruyucu etki göstermektedir. Mikro besin ögelerinden A, C, D ve E vitamini ile Çinko anti-inflamatuar etkiye sahiptir. İnflamatuar hücre kültürlerine retinoik asit eklendiğinde, TNF- $\alpha$, IL-1 $\beta$, IL-6 ve IL-12 salınımında azalma meydana gelmektedir. Uzun süre C vitamini desteği, CRP düzeyini azaltabilmektedir. D vitamini, inflamatuar sitokinlerin etkisini ve üretimini inhibe edebilmektedir. Alfa-tokoferol, IL-1 $\beta$, CRP ve TNF- $\alpha$ düzeyini azaltabilmektedir. Çinko, sitokin üretimini regüle ederek inflamasyonu baskılayabilmektedir. Besin tüketimi genel olarak büyük bir çeşitlilik göstermektedir dolayısıyla diyetin inflamasyona etkisi incelenirken bir bütün olarak değerlendirilmelidir. Diyetin inflamatuar potansiyelini değerlendirmek amaciyla, 1950'den 2010'a kadar yayınlanan bilimsel literatüre dayanan bir algoritma ile Diyet İnflamatuar İndeksi (DII) oluşturulmuştur. Yüksek DII skorları ve inflamasyon, pro-inflamatuar sitokinlerin osteoklast aktivitesini arttırıcı osteoblast aktivitesini azaltıcı etkileri ile, özellikle kadınlarda kemik kütle yoğunluğunun azalmasına ve kırık insidansının artmasına neden olabilmektedir. Kadınlar, postmenopozal dönemde, östrojen seviyelerindeki azalma sebebiyle daha yüksek kırık riski ile karşı karşıya kalırlar. Östrojen, osteoklast apoptozunu düzenler ve pro-inflamatuar sitokinleri inhibe eder. Epidemiyolojik çalışmalardan elde edilen veriler, Postmenopozal kadınlarda sağlıklı bir beslenme düzeni ve düşük DII skorlarının kemik sağlığının korunmasında etkili ve gerekli olduğunu desteklemektedir.

\section{ABSTRACT}

Inflammation is the body's immune response to inflammatory stimuli or tissue damage. While acute inflammation develops against injury and infectious agents, chronic inflammation is associated with insulin resistance, diabetes, atherosclerosis, obesity and metabolic syndrome. Dietary content may cause chronic inflammation in serum due to its effect on inflammation parameters such as CRP, IL-6 and TNF- $\alpha$. Excessive energy intake in the diet triggers inflammatory processes. In addition, macro and micronutrients included in the diet are effective on inflammatory processes. The source, type and amount of carbohydrates, proteins and fats, which are macro nutrients, affect the inflammation parameters. The diet is rich in simple carbohydrates, high glycemic index, high fat (especially the excess of trans fatty acids) and cholesterol, increases the release of pro-inflammatory molecules such as CRP, TNF- $\alpha$, IL-6, IL-

\footnotetext{
* Sorumlu yazar.

E-mail adresi: dytbetulyildirim1@gmail.com (Betül Yıldırım Çavak)
} 

against inflammatory response formation. Among the micronutrients, vitamin A, C, D and E and Zinc have anti-inflammatory effect. When retinoic acid is added to inflammatory cell cultures, TNF- $\alpha$, IL-1 $\beta$, IL-6 and IL-12 release decrease. Long-term vitamin C support can reduce CRP levels. Vitamin D can inhibit the action and production of inflammatory cytokines. Alphatocopherol can decrease the level of IL- $1 \beta$, CRP and TNF- $\alpha$. Zinc can suppress inflammation by regulating cytokine production. Food consumption generally varies widely, so it should be evaluated as a whole when examining the effect of diet on inflammation. In order to evaluate the inflammatory potential of the diet, the Diet Inflammatory Index (DII) was created with an algorithm based on scientific literature published from 1950 to 2010. With high DII scores and inflammation, the effects of pro-inflammatory cytokines that increase osteoclast activity, decrease bone mass density and increase the incidence of fractures, especially in women. Women are at higher risk of fractures in the postmenopausal period due to a decrease in estrogen levels. Estrogen regulates osteoclast apoptosis and inhibits pro-inflammatory cytokines. Data from epidemiological studies support that a healthy diet and low DII scores in postmenopausal women are effective and necessary in maintaining bone health.

\section{Giriş}

İnflamasyon, doku hasarı veya inflamatuar uyaran varlığında vücudun kendine özgü verdiği bir immün yanıttır. Akut inflamasyon yaralanma ve enfeksiyoz ajanlara karşı gelişirken, kronik inflamasyon insülin direnci, diyabet, ateroskleroz, obezite ve metabolik sendrom ile ilişkilidir (Kocamış, 2018). İnflamatuar biyobelirteçler; akut faz reaktanlarını [C reaktif protein (CRP), serum amiloid A gibi], sitokinleri [IL-6 (Interlökin 6), IL-8 (Interlökin 8), IL-10 (Interlökin 10), TNF- $\alpha$ (Tümör nekröz faktörü alfa) gibi], hücresel adezyon moleküllerini, lenfositlerin ve monositlerin aktivasyonunu içermektedir. Sitokinler; akut ve kronik inflamasyonda inflamatuar yanıtın yapısını, büyüklüğünü, süresini düzenlemede etkin moleküllerdir. Bunlardan IL-1 (Interlökin 1), IL-6, IL-8 ve TNF- $\alpha$ gibi sitokinler, proinflamatuar özellikleri ile bilinmektedir (Özenir, 2018). IL-6 (Interlökin 6): Hepatik akut faz proteinlerinden olan proinflamatuar sitokindir. CRP'nin üretilmesini ve diğer akut faz proteinlerinin artışını sağlamaktadır. CRP (C reaktif protein): Günümüzde enfeksiyonel hastalıkların belirlenmesinde ve izlenmesinde kullanılmaktadır. Yarı ömrü 19 saattir. IL-1 ve IL-6 varlığında temel olarak hepatositlerden, daha az oranda monositler, makrofajlar ve muhtemelen düz kas hücrelerinden üretilmektedir. İnflamatuar uyarı sonrası normalin 100 katı yüksek değerlere çıkabilen biyolojik bir belirteçtir. TNF- $\alpha$ (Tümör nekröz faktörü alfa): İnflamatuar hücre aktivasyonunda önemli bir role sahiptir. TNF- $\alpha$, insülin direncine sebep olabilmektedir (Özenir, 2018).

\section{Diyet ve İnflamasyon}

Diyet içeriği serumda CRP, IL-6 ve TNF- $\alpha$ gibi inflamasyon parametreleri üzerine etkisi ile kronik inflamasyona sebep olabilmektedir. Diyette gereksinimden fazla enerji alımı inflamatuar süreçleri tetikler. Bunun yanı sıra diyette yer alan makro- ve mikro besin ögeleri inflamatuar süreçler üzerinde etkilidir. Makro besin ögeleri olan karbonhidrat, protein ve yağların kaynağı, türü ve miktarı inflamasyon parametrelerini etkiler. Diyetin basit karbonhidrattan zengin olması, yüksek glisemik indeks, yüksek yağ (özellikle trans yağ asitlerinin fazlalığ 1 ) ve kolesterol içermesi CRP, TNF- $\alpha$, IL-6, IL-1 $\beta$ gibi pro-inflamatuar sitokinlerin salınımını arttırmaktadır. Günlük diyette tüketilen karbonhidratın kaynağı, türü ve miktarı, inflamatuar yanıt üzerine etkilidir. Sükroz, fruktoz gibi ilave şeker içeren yüksek basit karbonhidrat içeriğine sahip ürünlerin (işlenmiş karbonhidratlar ve sükroz/fruktoz ilaveli içecekler) fazla tüketimi bireylerin enerji alımını artırmakta ve sonuç olarak TNF- $\alpha$, IL-6, IL-1 $\beta$, CRP salınımına yol açmaktadır. Diyetin düşük glisemik indeks ve yüksek kompleks karbonhidrat içeriğine sahip olması ise inflamatuar yanıt oluşumuna karşı koruyucu etki göstermektedir. Yüksek posa içeriği (30 g/gün) olan beslenme örüntüsü inflamasyona karşı koruyucu etkiye sahiptir. Günlük diyette tüketilen protein miktarı, kaynağı (bitkisel protein, hayvansal protein) ve diyetin amino asit örüntüsü inflamatuar yanıt üzerine etkilidir. Diyetin yă̆ asidi örüntüsü, toplam yağ miktarı ve tüketimi inflamatuar yanıt üzerine etkilidir. Diyetin yüksek yağ ve kolesterol içeriği TNF- $\alpha$, IL- $1 \beta$, IL-6 gibi proinflamatuar sitokinlerin salınımını artırmaktadır. İşlenmiş ürünlerin tüketimiyle birlikte diyette miktarı yükselen doymuş yağ asitleri (SFA) ve trans yağ asitleri (TFA) de inflamasyona yol açar. Doymuş yağ asitleri ve trans yağ asitlerinin aksine, diyetin tekli doymamış yağ asitleri (MUFA) ve çoklu doymamış yağ asitleri (PUFA) inflamasyona karşı koruyucu etki göstermektedir (Bodur, 2019). Düşük yă̆ tüketimi, inflamasyonu azaltıcı etkiye sahiptir. Omega-3 yağ asidi tüketimi, metabolik sendrom ve düşük düzeyli inflamasyona karşı obez bireyleri koruyabilmektedir. Balık yağı tüketimi, pro-inflamatuar sitokin üretimini baskılayıp, CRP, IL-6 ve TNF- $\alpha$ düzeyini azaltabilmektedir (Özkan vd., 2017).

Mikro besin ögelerinden A, C, D ve E vitamini ile Çinko antiinflamatuar etkiye sahiptir. A vitamini anti-inflamatuar ajan olarak rol oynamaktadır. İnflamatuar durumlarda, A vitamini desteğinin yararlı etkilerinin olduğu bulunmuştur. İnflamatuar hücre kültürlerine retinoik asit eklendiğinde, TNF- $\alpha$, IL-1 $\beta$, IL-6 ve IL-12 salınımında azalma meydana gelmektedir. C vitamini inflamasyon göstergelerini azaltarak anti-inflamatuar etki gösterebilmektedir. Kısa süreli tüketiminde bu etki gözlenmese de Uzun süre C vitamini desteği, CRP düzeyini azaltabilmektedir. D vitamini, inflamatuar sitokinlerin etkisini ve üretimini inhibe edebilmektedir. Anti-inflamatuvar sitokinlerin üretiminin artırılması süreçlerine katılabilmektedir. Alfa-tokoferol, IL-1 $\beta$, CRP ve TNF- $\alpha$ düzeyini azaltabilmektedir. Çinko, sitokin üretimini regüle ederek inflamasyonu baskılayabilmektedir. Diyetle çinko verilmesi, kronik inflamatuar hastalıklarda iyileşmeye katkı sağlayabilmektedir (Özkan vd., 2017).

\section{Diyet Inflamatuar İndeksi}

İnsanlar besinleri tek başına tüketmezler. Besin tüketimi genel olarak büyük bir çeşitlilik göstermektedir. Besin maddelerinin hastalık sonuçlarıyla ilişkili olarak incelenmesi, diyet kalıplarına kıyasla daha zayıf ilişkiler sağlayabilir. Dolayısı ile diyetin inflamasyona etkisi incelenirken bir bütün olarak değerlendirilmelidir. Diyetin inflamatuar potansiyelini değerlendirmek amacıyla, 1950'den 2010'a kadar yayınlanan bilimsel literatüre dayanan bir algoritma ile Diyet İnflamatuar 
İndeksi (DII) oluşturulmuştur. Bu indeks: diyetin inflamatuar özelliklerine odaklanan ilk indeksir. Besinlerin inflamasyon üzerine spesifik etkilerini inceleyen makaleler kullanılarak oluşturulmuştur ancak diyeti bir bütün olarak değerlendirir. DII, mikrobesinler ve makrobesinler ile sınırlı değildir, aynı zamanda flavonoidler, baharatlar ve çay da dahil olmak üzere yaygın olarak tüketilen biyoaktif bileşenleri içerir. Spesifik inflamatuar biyobelirteçlerin (IL-1 $\beta$, IL-4, IL-6, IL-10, TNFa ve CRP) seviyelerini olumlu veya olumsuz etkilediği bildirilen her yiyecek ve bileşen (örneğin, besinler ve flavonoidler dahil diğer parametreler) için bir puan atanarak oluşturulmuştur. DII skorlaması, belirli popülasyona bağlı değildir. Küresel bir veritabanı üzerine oluşturulmuştur (Shivappa vd., 2014).

\section{İnflamasyon ve Kırık İlişkisi}

Diyet indeksleri, diyet ve kronik hastalıklar arasındaki ilişkilerin incelenmesinde alternatif ve tamamlayıcı yaklaşımlar olarak kullanılmaktadır. DII, bireyin diyetini maksimum anti-inflamatuardan maksimum pro-inflamatuara kadar bir süreklilikte değerlendirebilecek bir araçtır. Yüksek DII skorları ve inflamasyon, pro-inflamatuar sitokinlerin osteoklast aktivitesini arttırıcı osteoblast aktivitesini azaltıcı etkileri ile, özellikle kadınlarda kemik mineral yoğunluğunun azalmasına ve kırık insidansının artmasına neden olabilmektedir (Tabung vd., 2014). İnflamasyon, çeşitli mekanizmalarla kemik kütle yoğunluğunu azaltabilmektedir. CRP, TNF-a, IL-1 ve IL-6 da dahil olmak üzere inflamatuar sitokinler perimenopozal ve postmenopozal osteoporozun patogenezinde potansiyel kritik roller oynayabilmektedir. Proinflamatuar sitokinlerin osteoklastların aşırı aktivasyonuna ve osteoblast aktivitesinin azalmasına neden olabileceği bildirilmiştir. Sekiz yıllık takip süresi içeren bir çalışmada, daha yüksek DII skorları ile belirtildiği gibi daha proinflamatuar bir diyetin kadınlarda daha yüksek kırık insidansı ile ilişkili olduğunu bulunmuştur. DII skoru en yüksek olan yani daha pro-inflamatuar bir diyete sahip kadınlarda kırık riski \%46 daha yüksek bulunmuştur. Bu bulgular erkeklerde anlamlı bulunmamıştır ve önemli cinsiyet farklılıkları olduğunu düşündürmüştür (Veronese vd., 2018). Barbour ve ark. (2014), yüksek inflamasyon seviyelerinin kalça kırı̆̆1 riskini artırıp artırmadığını belirlemek için 4709 kadından oluşan popülasyonda bir araştırma yapmışlardır. 10-16 yıl boyunca dört ayda bir katılımcıların kan tahlilleri ile IL-6, TNF-a ve IL-6'nın ve TNF-a'nın çözünür reseptörlerinin (SR) seviyeleri ölçülmüştür ve kalça kırığı takibi yapılmıştır. İnflamatuar yükün, kemik mineral yoğunluğunun düşmesine bağlı olarak kalça kırıkları ile ilişkili olduğunu belirlemişlerdir. İnflamasyonu azaltmanın, yaşı kadınlarda kalça kırı̆̆ı riskini azaltmak için etkili bir yaklaşım olabileceğini bildirmişlerdir (Barbour vd., 2014). Zhang ve ark. (2017), daha yüksek DII skorlarının yaşlılarda daha fazla kalça kırığı riski ile ilişkili olduğu hipotezini test etmek amacıyla Çin'de bir çalışma yapmışlardır. 52-83 yaş aralığındaki 1050 kişi ile yapılan olgu-kohort çalışması sonucunda pro-inflamatuar bir diyetin kalça kırığı riski ile pozitif ilişkili olduğuna ulaşmışlardır (Zhang vd., 2017). Cauley ve ark. (2007), 70-79 yaş aralığında 2985 katılımcı ile yaptıkları bir çalışmada sitokinlerin kırık riski ile ilişkisini araştırmışlardır. İnterlökin, TNF-a, C-reaktif protein ve çözünür reseptörlerinin serum seviyeleri ölçülmüştür ve en fazla inflamatuar biyobelirtece sahip katılımcıların en yüksek kırık riskine sahip olduğu belirlenmiştir (Jauley vd., 2007).

\section{Diyet ve Kırık İlișkisi}

Kemik, sürekli yeniden yapılanma ve onarım geçiren dinamik bir dokudur. Bir kadının en yüksek kemik kütlesi yaklaşık 19 yaşında elde edilirken, en büyük kemik kaybı süresi menopoz sırasında östrojen seviyelerindeki azalma ile ilişkilidir (Mucowski vd., 2014). Kalça kırıkları ve diğer birçok kırık tipi menopoz sonrası kadınlarda ve yaşlı erkeklerde kemiklerinin yaşa bağlı zayıflaması ve osteoporoz nedeniyle çok yaygındır. Magnezyum (Mg) kas gücünü destekleyen ve bu sayede düşme ve düşmeye bağlı kırık riskini azaltan bir mineraldir. Ayrıca, anti-inflamatuar etkiye sahiptir ve inflamasyonun yol açtığı osteoporoz ve kemik kırıklarına karşı koruyucudur. Birçok açıklama osteoporoz ve kırıkların önlenmesinde magnezyumun rolünü desteklemektedir. $\mathrm{Mg}$, kalsitriol ve paratiroid hormonunun düzenlenmesi yolu ile osteoblastlar ve osteoklastların işlevini olumlu yönde etkileyen ve kalsiyum homeostazını modüle eden kemik sağlığı ile ilişkili bir mineraldir. Mg, DII skoru düşük olan yeşil sebzelerde, kabuklu yemişlerde, tahıllarda ve Akdeniz diyetinin kadınlarda kemik kırıkları üzerinde önemli bir koruyucu etkiye sahip diğer bileşenlerinde bulunur. Mg'nin kırıklar üzerindeki etkisinin kadınlarda erkeklerden daha önemli olduğu belirtilmiştir. Özellikle menopozdan sonra kadınların mikrobesin alımının erkeklere göre azaldığı bilinmektedir ve bu da onları beslenme eksikliklerinin sonuçlarına daha duyarlı hale getirmektedir. Yapılan bir çalışmada, daha yüksek diyet Mg alımı, 8 yıllık takip süresinde kırık riskinde anlamlı bir azalma ile ilişkilendirilmiştir. En yüksek $\mathrm{Mg}$ alımına sahip olan erkeklerin kırık riskinde $\% 53$ ve kadınların $\% 62$ oranında önemli bir azalma yaşadığı sonucuna ulaşılmıştır. Çalışmalar, daha yüksek diyet $\mathrm{Mg}$ alımının osteoporoz ve kırıklarda önemli bir rol oynadığını ve bu mineralin özellikle kadınlarda kemik osteoporotik kırıklara karşı koruyucu etkisi olduğunu göstermiştir (Veronese vd., 2017). D vitamini, güçlü kemik oluşturmak için gereklidir. Esas olarak bağırsak, böbrekler ve kemik üzerinde etkili olan, mineral homeostazı üzerinde bilinen biyolojik etkileri olan bir dizi ajandır. Bağırsak kalsiyum emilimi uyarılır ve kemik kütlesi korunur. Yaşlı insanlar genellikle yetersiz güneş 1şı̆̆ı alımı ve diyet ile düşük $\mathrm{D}$ vitamini alımı nedeniyle düşük $\mathrm{D}$ vitamini seviyelerine sahiptir. Bu nedenle, takviyeler şeklinde ek D vitamini alımının kalça ve diğer kemiklerin kırık riskini azaltmaya yardımcı olabileceği önerilmiştir. Sadece D vitamininin, yaşlılarda şimdiye kadar test edilen dozlarda ve formülasyonlarda kırıkları önleme olasılığı düşüktür. D vitamini ve kalsiyum takviyelerinin kalça kırıklarını veya herhangi bir kırı̆̆ı önleyebileceği bildirilmiştir (Avenell, 2014). A vitaminin ciddi yetersizliği değişik kemik anomalilerine neden olabilmektedir. Bazı in vitro çalışmalar retinoik asidin doğrudan osteokalstik kemik emilimini stimüle ettiğini gösterirken bazı çalışmalar retinolün osteoblastik hücre poliferasyonunda inhibitör etkisi olduğunu göstermektedir (Tüccar, 2017). C vitamininin kemik sağlı̆ı üzerine etkilerini değerlendiren çalışmaların çoğunda, çalışma popülasyonunu 60 yaşından büyük bireyler ve/veya postmenopozal kadınlar oluşturmaktadır. $\mathrm{Bu}$ gruplarda osteoporoz prevalansı ve osteoporotik kırık insidansı en yüksektir. İnsan çalışmalarının büyük çoğunluğu gözlemsel olmuştur ve iskeletsel bir sonuç olarak kemik mineral yoğunluğu düzeyini veya kemik mineral yoğunluğundaki değişikliği zaman içinde değerlendirmiştir. Çok sayıda 
çalışma, postmenopozal kadınlarda çok değişkenli lineer regresyon modellemesi kullanarak diyet $C$ vitamini alımı ve kemik mineral yoğunluğu arasındaki ilişkiyi incelemiştir. Bir veya daha fazla kemik bölgesinde diyet $C$ vitamini alımı ile kemik mineral yoğunluğu arasında anlamlı pozitif korelasyonlar gözlemlenmiştir. Yapılan çalışmaların çoğu, serum C vitamini seviyelerinin veya alımının azalmasının osteoporoz gelişimi ve artan kırık riski ile ilişkili olabileceği sonucuna işaret etmektedir (Aghajanian, 2015). K vitamini (özellikle menakinon-4), osteoblast farklılaşmasını uyararak, çoğalmalarını indükleyerek, osteojenik genlerin ekspresyonunu artırarak osteoblastların işlevini geliştirir. Bazı kemik oluşumu belirteçlerinin (örn., Alkalin fosfataz ve insülin benzeri büyüme faktörü) seviyesini artırarak ve hücre dışı matris mineralizasyonunu Y-glutamil karboksilasyon yoluyla düzenleyerek kemik oluşumunu destekler. Ek olarak, $\mathrm{K}$ vitamini, osteoklast farklılaşmasını azaltarak ve osteoblast apoptozunu inhibe ederek antikatabolik aktiviteleri yoluyla kemik emilimini önler (Akbari ve Rasouli-Ghahroudi, 2018). Diyet faktörleri de besin emilimini ve metabolizmasını etkilemek için birbirleri ile etkileşime girebilir. Örneğin, fazla fosfor veya oksalat alımı kalsiyum emilimini azaltabilir ve fazla sodyum alımı kalsiyum atılımını artırabilir. Bu nedenle, diyet ve kalça kırıkları arasındaki ilişkiyi incelemek için bir yaklaşım, diyetin birden fazla bileşenini aynı anda incelemektir. Bazı araştırmacılar, bir popülasyonda baskın diyet kalıplarını yakalamak için temel bileşen analizini kullanarak ve kırık riski ile ilişkilerini incelemişlerdir. Bunlar arasında, Çinliler üzerinde yapılan bir araştırmada, sebze, meyve ve soyadan yüksek bir diyet kalıbı bulunmuştur. Hem erkeklerde hem de kadınlarda kalça kırığı riski düşüktür. Kanada'da yapılan bir araştırmada ise, meyve, sebze ve kepekli tahılların daha fazla alımı ile karakterize edilen bir diyet kalıbı bulunmuştur. Bu diyet kalıbı, kadınlarda toplam travmatik olmayan kırık riskinin daha düşük olması ile ilişkili bulunmuştur (Fung ve Feskanich, 2015). Çeşitli tanımlayıcı epidemiyolojik çalışmalar, osteoporoz ve osteoporoz ile ilişkili kırıkların insidansının, kuzey Avrupa ülkelerine kıyasla Akdeniz'de daha düşük oranlarda olma eğilimi ile uluslar arasında değiştiğini göstermiştir. $\mathrm{Bu}$ farklılıklar, spesifik diyet modelleri de dahil olmak üzere yaşam tarzı faktörlerine bağlanmıştır. Geleneksel Akdeniz tarzı diyet, kemik sağlığı üzerinde faydalı etkiler sağladığı olarak gösterilen bitkisel gıdalar, balık, fındık ve tekli doymamış yağ gibi diyet bileşenlerinin tüketimini vurgular. Postmenopozal kadınlarda büyük bir popülasyonda diyet önerileri veya mevcut sağlıklı diyet kalıplarının kemik kırılganlığı (kalça veya total kırıklar) üzerine etkisini incelemek amaciyla yapılan bir çalışmada, Akdeniz diyetine bağlılık ile karakterize edilen yüksek diyet kalitesinin, kalça kırıkları için daha düşük bir risk ile ilişkili olduğu görülmüştür. Meyve, sebze, balık, kuruyemiş, baklagiller ve kepekli tahılların tüketimini ve kırmızı ve işlenmiş etlerin tüketiminden kaçınmayı vurgulayan Akdeniz beslenme düzenine çok bağlı kadınlarda; kalça kırığı riski daha düşük bulunmuştur, ancak mutlak risk azalmasının küçük olduğu bildirilmiştir. Bu sonuçlar postmenopozal kadınlarda sağlıklı bir beslenme düzenini izlemenin kemik sağlı̆̆ının korunmasında rol oynayabileceği fikrini desteklemektedir (Haring vd., 2016). Kadınlarda menopoz geçişi, asit-baz dengesizliği, östrojen eksikliği ve hızlı kemik kaybı ile karakterizedir. Diyet ve dolayısı ile beslenmenin, osteoporoz gibi metabolik kemik bozukluklarının yönetimi ve muhtemelen önlenmesi için yararlı ve değiştirilebilir araçlar olduğu gösterilmiştir. Tek bir besinin araştırılması yararlı olsa da, besin kombinasyonlarının araştırılması, besinlerin birlikte tüketildiklerinde kemik sağlığ1 üzerine sinerjik ve antagonistik etkilerini dikkate alarak farklı çevre, kültür, yemek alışkanlıkları ve tercihleri olan bireylere yardımcı olabilmektedir. Yüksek meyve ve sebze tüketimi alkali bir diyet ile ilişkilidir. Alkaliliği oluşturan metabolitlerden yoksun olan Batı diyeti, osteoporoz prevalansının yüksek olması için bir etken olarak kabul edilmiştir. Doymuş yağ asitleri bakımından da yüksek olan Batı diyeti, kalsiyumun biyolojik olarak bulunabilirliğini ve biyolojik olarak erişilebilirliğini etkiler. Postmenopozal kadınlarda, yüksek yağlı bir besin deseni ile birlikte yaşla birlikte artan bir asitliğin kemik mineral yoğunluğu için zararlı olabileceği öne sürülmüştür (Ilesanmi-Oyelere, 2019).

\section{Menopoz ve Kırık İlişkisi}

Dengeli bir diyet, düzenli fiziksel aktivite, yeterli bir vücut kitle indeksi ve menarş yaşı, gebelik durumu ve emzirme gibi bazı jinekolojik faktörler perimenopozal ve postmenopozal kadınlarda kemik mineral yoğunluğu üzerine etkilidir (Méndez-Gallegos vd., 2018). Kemik mineral yoğunluğunun düşüş hızında önemli cinsiyet farklılıkları vardır. Kadınlar menopoz dönemine geçiş sırasında kemik mineral yoğunluğunda büyük bir azalma yaşarlar. Menopozdan sonra da erkeklere kıyasla kemik mineral yoğunluğunda azalma daha fazla olarak devam eder. Pro-inflamatuar sitokinlerden olan IL-6 osteoklast öncü hücrelerinin olgun osteoklastlara farklılaşmasına neden olur. Osteoklast oluşumuna ve kemik rezorpsiyonuna sebep olur. IL-6 dahil pro-inflamatuar sitokinlerin aktiviteleri östrojen tarafindan baskılanır. Östrojen, kemik ve diğer dokulardaki reseptörler ile etkileşime girerek kemik sağlığına katkı sağlar. Östrojen, osteoklast apoptozunu düzenleyebilmektedir; östrojen eksikliği durumunda, osteoklastlar daha uzun yaşar ve kemik emilimini arttırır (Mitchell ve Yerges-Armstron, 2011). Kadınlar ve erkekler yetişkinlik döneminde kemik kütlesinde kayıp yaşamaya başlar. Menopoz dönemine yaklaştıkça kadınlarda endojen östrojen üretimi azalır ve bu durum kemik mineral kaybı ve kemik yapısının zayıflamasına yol açar. Bu durum kırık riskini arttırır. Kadın Sağlığı Girişimi'ne (WHI) kayıtlı 137.486 postmenopozal Amerikalı kadın ile yapılan bir çalışmada, daha yüksek PUFA tüketimi, takipten sonra daha düşük kırık riski ile ilişkili bulunmuştur. İnsan çalışmalarından elde edilen bulgular, daha yüksek PUFA tüketiminin, daha yüksek kemik mineral yoğunluğu veya kadınlarda daha düşük kırılganlık kırığı riski ile ilişkili olduğunu göstermektedir (Longo ve Ward 2016). Yapılan çalışmalar menopoz dönemine normalden daha erken yaşta giren kadınların düşük kemik mineral yoğunluğuna sahip olduğunu göstermektedir. Gallagher, erken menopozun kemik üzerindeki etkisi ile ilgili verileri gözden geçirmek için İsveç'te bir araştırma yapmıştır. Erken menopozun kadınlarda kemik mineral yoğunluğunun düşmesine ve osteoporotik kırık insidansının artmasına etkisini araştırmıştır. Bu çalışmada menopoz dönemindeki 773 kadın 11 y1l boyunca izlenmiş ve erken menopoza giren kadınlarda ileri yaşlarda menopoza giren kadınlara kıyasla \%50 daha fazla kırık oluştuğu sonucuna ulaşılmıştır. Yaşamda menopoz ne kadar erken ortaya çıkarsa, kemik yoğunluğu yaşamda o kadar düşük olur. Düşük kemik yoğunluğu daha yüksek bir kırık oranı ile ilişkilidir (Gallagher, 2007). Francucci ve ark., menopoz 
zamanının sağlıklı postmenopozal kadınlarda vertebral kemik kütlesi üzerindeki etkilerini araştırmak ve erken menopozun daha düşük vertebral kemik mineral yoğunluğu için bir risk faktörü olup olmadığını değerlendirmek amacı ile kesitsel bir çalışma yürütmüşlerdir. Çalışma popülasyonu 45-75 yaşları arasındaki 782 kadından oluşmuştur. Katılımcılar; erken, normal ve geç menopozlu kadınlar olarak 3 gruba ayrılmıştır. $\mathrm{Bu}$ çalışmada menopoz yaşı ve menopozdan bu yana geçen yıllar arasında anlamlı farklılıklar bulunmuştur. Çalışmada, 50-54 yaş aralığında erken menopozlu kadınların normal menopoz ve geç menopozlu kadınlardan daha düşük vertebral kemik mineral yoğunluğuna sahip olduğu görülmüştür. 55 yaşın üzerinde, erken menopoz, normal menopoz ve geç menopozlu kadınlarında lomber kemik mineral yoğunluğu değerleri açısından fark görülmemiştir. Tartışmalı veriler erken menopozdan sonra kemik kaybının, normal veya geç menopozdan daha yüksek olduğunu göstermiştir (Francucci vd., 2008). Tüccar ve ark.'nın Ankara'da yürüttükleri bir çalışmada; premenopozal ve postmenopozal kadınlarda FRAX (Fracture Risk Assessment Tool) değerlendirme arac1 ile hesaplanan 10 yıllık kırık riski ile besin tüketim durumu arasındaki ilişki incelenmiştir. Çalışma popülasyonunu 40-60 yaş arası premenopoz döneminde olan veya doktor tarafından menopoza girdiği saptanmış 300 kadın oluşturmaktadır. Bu çalışma sonucunda literatür ile benzer olarak, premenopozal ve postmenopozal kadınların majör osteoporotik kırık riski ve kalça kırığı riski arasındaki fark istatistiksel olarak anlamlı bulunmuştur (Tüccar, 2017). Mendoza ve ark., diyetin kemik mineral yoğunluğu ve osteoporoza etkisinin önemini incelemek üzere İspanya' da bir çalışma yapmışlardır. Çalışma popülasyonunu osteoporoz grubunda 450 postmenopozal kadın, osteopeni grubunda 766 kadın ve kontrol grubunda 479 kadından oluşmaktadır. Östrojenik aktivite dönemini sınırlamak ve menopoz döneminin osteoporoza etkisini değerlendirmek için kadınların menarş yaşı ve menopoz yaşı çalışma verilerine kaydedilmiştir. Daha ileri seviyede osteoporoza sahip kadın grubunun menarş ve menopoz yaşlarının daha erken olduğu görülmüştür. $\mathrm{Bu}$ bulgu ile uyumlu olarak, osteoporozlu hastalar arasında belirgin olarak daha fazla erken menopoz (40 yaşından önce meydana gelen) vakası olduğu görülmüştür. Yazarlar, bu veriler ile osteoporozun östrojene bağımlı bir hastalık olduğu ve daha kısa doğurganlık dönemleri yaşayan kadınların hastalığ geliştirme olasılığının daha yüksek olduğunu doğrulamışlardır

\section{Sonuç}

Menopoz sonrası kadınlarda; mineral yoğunluğunun düşmesi ile kemiklerin yaşa bağlı olarak zayıflaması, osteoporoz, östrojen seviyelerindeki azalma ve dolayısı ile östrojenin kemik sağlığını koruyucu etkisinin azalması nedeniyle kalça kırıkları ve diğer birçok kırık tipinin görülmesi yaygındır. Epidemiyolojik çalışmalardan elde edilen veriler, postmenopozal kadınlarda sağlıklı bir beslenme düzeni ve düşük Diyet İnflamatuar İndeksi skorlarının kemik sağlığının korunmasında etkili ve gerekli olduğunu desteklemektedir.

\section{Kaynaklar}

Aghajanian, P., Hall, S., Wongworawat, Md., Mohan, S., (2015). The Roles And Mechanisms Of Actions Of Vitamin C İn Bone: New Developments. J Bone Miner Res., 30(11):1945-55. Doi: 10.1002/Jbmr.2709.

Akbari, S., Rasouli-Ghahroudi, Aa., (2018). Vitamin K And
(Mendoza, 2013). Diyetin kemik mineral yoğunluğu ve osteoporoza etkisinin incelendiği bu çalışmada, alkali diyetin (yüksek magnezyum, potasyum, meyve ve sebze içeren diyet) kemik mineral yoğunluğunu artırdığı ve asidik diyetlere (yüksek protein içeren diyet) kıyasla kemik kaybını önlediği, tahıl ve sebze tüketiminin kalça kemik mineral yoğunluğu üzerine koruyucu etki gösterdiği sonuçlarına ulaşılmıştır (Mendoza, 2013). Moschonis ve ark., Ca (kalsiyum) ve D vitamini eklenmiş süt ürünlerinin takviyesi ile yaşam tarzı ve beslenme danışmanlığı seanslarının menopoz sonrası kadınların kemik mineral yoğunluğu üzerine etkilerini araştırma amacı ile bir çalışma yapmışlardır. Çalışma popülasyonu 55-65 yaş aralığındaki 66 postmenopozal kadından oluşmuştur. Diyet müdahalesi 30 ay boyunca uygulanmış ve etkileri izlenmiştir. Sonuç olarak bu çalışmada, yaşam tarzı ve beslenme danışmanlığı seanslarının sağladığı uyum ile 30 ay boyunca takviye edilmiş süt ürünleri ile önerilen $1200 \mathrm{mg}$ değerine yakın ve Ca ve yaklaşı $22.5 \mu \mathrm{g} / \mathrm{L}$ D vitamini alımının sağlanmasının postmenopozal kadınlarda kol, total omurga ve toplam vücut kemik mineral yoğunluğu değişiklikleri üzerine olumlu etkilere sahip olabileceğine ulaşılmıştır (Moschonis vd., 2010). Kronik inflamasyon, osteoporoz ve kırılganlık kırıkları da dahil olmak üzere yaşa bağlı çeşitli hastalıkların artmış riski ile ilişskilidir. Daha yüksek serum inflamatuar belirteç seviyeleri yaşlı erişkinlerde kemik kaybını ve artmış kemik rezorpsiyonunu öngörür. Büyük, Prospektif epidemiyolojik çalışmalardan elde edilen veriler bu öngörüyü desteklemiştir ve daha yüksek serum inflamatuar belirteçlerinin yaşı kadınlarda ve erkeklerde daha fazla kırık riski ile ilişkili olduğu tespit edilmiştir. Ancak, menopoz sonrası kadınlarda kırık riskini azaltmak için tek bir gıda veya besin maddesi yeterli olmayabilir. Yapılan çalışmalarda, DII skoru daha düşük olan postmenopozal kadınlarda başlangıçta kalça kemik mineral yoğunluğu daha düşük olmasına rağmen, daha inflamatuar bir diyet tüketen kadınlara kıyasla 6 yıl boyunca kalçada daha az kemik mineral yoğunluğu kaybı yaşandığı görülmüştür. Daha inflamatuar bir diyet tüketiminin, genç beyaz kadınlarda da artmış kalça kırığı riski ile ilişkili olduğu bulunmuştur. Daha çeşitli popülasyonlar arasında bu bulguları doğrulamak için daha fazla araştırma yapılması gerektiği bildirilmiştir (Orchard vd., 2017).

Bone Metabolism: A Review Of The Latest Evidence İn Preclinical Studies. Biomed Resa Int.,2018:4629383. Doi:10.1155/2018/4629383.

Avenell, A., Mak, Jc., O'connell, D., (2014). Vitamin D And Vitamin D Analogues For Preventing Fractures İn Post-Menopausal Women And Older Men. Cochrane Database Syst Rev.,2014(4): Cd000227. Doi:10.1002/14651858.Cd000227.Pub4.

Barbour, K., Lui, L., Ensrud, K., Hillier, T., Leblanc, E., Ing, S., Hochberg, M., Cauley, J., (2014). Inflammatory Markers And Risk Of Hip Fracture İn Older White Women: The Study Of Osteoporotic Fractures. J Bone Miner Res., 29(9): 2057-2064. Doi:10.1002/Jbmr.2245.

Bodur, M., (2019). Diyetle Alınan Doymuş Yağ Asitleri Veya Fruktozun Böbrek Ve Kalpte Bazı Pro-İnflamatuar Sitokinler Üzerine Etkisi. Hacettepe Üniversitesi Sağlık Bilimleri Enstitüsü Toplu Beslenme 
Sistemleri Programı Yüksek Lisans Tezi, Ankara,Türkiye, 18-23 S.

Cauley, Ja., Danielson, Me., Boudreau, Rm., Forrest, Ky., Zmuda, Jm., Pahor, M.,Tylavsky, Fa., Cummings, Sr., Harris, Tb., Newman, Ab., (2007). Inflammatory Markers And Incident Fracture Risk İn Older Men And Women: The Health Aging And Body Composition Study. J Bone Miner Res., 22(7):108895. Doi: 10.1359/Jbmr.070409.

Francucci, Cm., Romagni, P., Camilletti, A., Fiscaletti, P., Amoroso, L., Cenci, G., Morbidelli, C., Boscaro, M., (2008). Effect Of Natural Early Menopause On Bone Mineral Density. Maturitas.,59(4):323-8. Doi:10.1016/J.Maturitas.2008.03.008.

Fung, T., Ve Feskanich, D., (2015). Dietary Patterns And Risk Of Hip Fractures İn Postmenopausal Women And Men Over 50 Years. Osteoporos Int., 26(6): 18251830. Doi: 10.1007/S00198-015-3081-6.

Gallagher, Cj., (2007). Effect Of Early Menopause On Bone Mineral Density And Fractures. Menopause., 14(3 Pt 2):567-71. Doi: 10.1097/Gme.0b013e31804c793d.

Haring, B., Crandall, Cj., Wu, C., Leblanc, Es., Shikany, Jm., Carbone, L., Orchard, T., Thomas, F., WactawaskiWende, J., Li, W., Cauley, Ja., Wassertheil-Smoller, S., (2016). Dietary Patterns And Fractures İn Postmenopausal Women Results From The Women's Health Initiative. Jama Intern Med., 176(5):645-52.

Doi:10.1001/Jamainternmed.2016.0482.

Ilesanmi-Oyelere, B1., Brough, L., Coad, J., Roy, N., Kruger, Mc., (2019). The Relationship Between Nutrient Patterns And Bone Mineral Density İn Postmenopausal Women. Nutrients., 11(6):1262. Doi: $10.3390 / \mathrm{Nu} 11061262$.

Kocamış, R., (2018). Yetişkin Bireylerde Diyetin İnflamatuvar İndeksi İle Beslenme Durumları Arasındaki İlişkinin Saptanması. Başkent Üniversitesi Sağlık Bilimleri Enstitüsü Beslenme Ve Diyetetik Anabilim Dalı Yüksek Lisans Tezi, Ankara, Türkiye, 5S.

Longo, Ab., Ve Ward, We., (2016). Pufas, Bone Mineral Density, And Fragility Fracture: Findings From Human Studies. Adv Nutr.,7(2):299-312. Doi: 10.3945/An.115.009472.

Méndez-Gallegos, E., Caire-Juvera, G., Astiazarán-García, H., Méndez-Estrada, Ro., (2018). Comparison Of Measurements Of Bone Mineral Density İn Young And Middle Aged Adult Women İn Relation To Dietary, Anthropometric And Reproductive Variables. Nutrients.10(11):1669. Doi: 10.3390/Nu10111669.

Mendoza, N., Martínez-Amat, A., Hita-Contreras, F., (2013). The İmportance Of Diet İn Osteoporosis. Open Journal Of Epidemiology 03(02):79-84. Do1: 10.4236/Ojepi.2013.32012.

Mitchell, Bd., Ve Yerges-Armstrong Lm., (2011). The Genetics Of Bone Loss: Challenges And Prospects. J Clin Endocrinol Metab., 96(5):1258-68. Doi: 10.1210/Jc.2010-2865. Epub 2011 Feb 23.

Moschonis, G., Katsaroli, I., Lyritis, Gp., Manios, Y., (2010). The Effects Of A 30-Month Dietary Intervention On Bone Mineral Density: The Postmenopausal Health Study. Br J Nutr., 104(1):100-7. Doi:
10.1017/S000711451000019x.

Mucowski, Sj., Mack, Wj., Shoupe, D., Kono, N., Paulson, R., Hodis, Hn., (2014). The Effect Of Prior Oophorectomy On Changes İn Bone Mineral Density And Carotid Artery Intima-Media Thickness İn Postmenopausal Women. Fertil Steril., 101(4):111722. Doi: 10.1016/J.Fertnstert.2013.12.055.

Orchard, T., Yildiz, V., Steck, Se., Hébert, Jr., Ma, Y., Cauley, Ja., Li W., Mossavar415 Rahmani, Y., Johnson, Kc., Sattari, M., Leboff, M., Wactawski-Wende, J., Jackson, Rd., (2017). Dietary Inflammatory Index, Bone Mineral Density, And Risk Of Fracture İn Postmenopausal Women: Results From The Women's Health Initiative. J Bone Miner Res., 32(5):1136-1146. Doi: 10.1002/Jbmr.3070. Epub $2017 \mathrm{Feb} 21$.

Özenir, Ç., (2018). Farklı Beden Kütle İndeksine Sahip Kadınların Beslenme Durumunun Bazı İnflamasyon Belirteçleri İle İlişkisinin Değerlendirilmesi. Hacettepe Üniversitesi Sağlık Bilimleri Enstitüsü Beslenme Ve Diyetetik Programı Doktora Tezi, Ankara,Türkiye, 24-26 S.

Özkan,G., Ersoy, G., Dayan, A., (2017). Enerji Ve Besin Ögeleri Alımının İnsülin Direnci Ve İnflamasyon Bulguları Üzerine Etkileri. Bes. Diy. Derg, 45(3):214-224.

Shivappa, N., Steck,S., Hurley, T., Hussey, J., Hébert, J., (2014). Designing And Developing A LiteratureDerived, Population-Based Dietary İnflammatory İndex. Public

Health Nutr, 17(8): 1689-1696. Doi: 10.1017/S1368980013002115.

Tabung, F., Steck, S., Zhang, J., Ma, Y., Liese, A., Agalliu, I., Hingle, M., Hou, L., Hurley,T., Jiao, L., Martin, L., Millen, A., Park, H., Rosal, M., Shikany, J., Shivappa, N., Ockene, J., Heberta, J., (2015). Construct Validation Of The Dietary Inflammatory Index Among Postmenopausal Women. Ann Epidemiol., 25(6): 398-405. Doi: 10.1016/J.Annepidem.2015.03.009.

Tüccar, Gt., Bakırarar, B., Köksal, E., (2017). Pre Ve Postmenopozal Kadınlarda Besin Tüketim Durumu Frax ${ }^{\circledR}$ Kırık Riski İle İlişkili Midir? Bes Diy Derg., 45(2):116-127.

Veronese, N., Stubbs, B., Koyanagi, A., Hébert, J., Cooper, C., Caruso, M., Guglielmi, G., Reginster, J., Rizzoli,R., Maggi, S., Shivappa, N., (2018). ProInflammatory Dietary Pattern Is Associated With Fractures In Women: An Eight Year Longitudinal Cohort Study. Osteoporos Int., 29(1): 143-151. Doi: 10.1007/S00198-017-4251-5.

Veronese, N., Stubbs, B., Solmi, M., Noale, M., Vaona, A., Demurtas, J., Maggi, S., (2017). Dietary Magnesium Intake And Fracture Risk: Data From A Large Prospective Study. Br J Nutr., 117(11):1570-1576. Doi: $10.1017 /$ S0007114517001350.

Zhang, Z., Cao, W., Shivappa, N., Hebert, J., Li, B., He, J., Tang, X., Liang, Y., Chen, Y., (2017). Association Between Diet Inflammatory Index And Osteoporotic Hip Fracture İn Elderly Chinese Population. J Am Med Dir Assoc., 18(8):671-677. Doi: 10.1016/J.Jamda.2017.02.011. 